\title{
GROWTH AND MEAT QUALITY OF PRESTICE BLACK-PIED AND (LANDRACE × LARGE WHITE) $\times$ DUROC PIGS
}

\author{
Pavel Nevrklaㄹ, Eva Václavková², Pavel Horký ${ }^{2}$ Vendula Kamanovál, Zdeněk \\ Hadaš ${ }^{1}$ Zuzana Rečková , Ladislav Máchal ${ }^{1}$

\begin{abstract}
${ }^{1}$ Department of Animal Breeding, Faculty of AgriSciences, Mendel University in Brno, Zemědělská 1, 61300 Brno, Czech Republic

${ }^{2}$ Institute of Animal Science, Prague-Uhřiněves, Kostelec nad Orlicí, Komenského 1239, 517 41, Czech Republic ${ }^{3}$ Department of Animal Nutrition and Forage Production, Faculty of AgriSciences, Mendel University in Brno, Brno, Zemědělská 1, 61300 Czech Republic
\end{abstract}

\begin{abstract}
NEVRKLA PAVEL, VÁCLAVKOVÁ EVA, HORKÝ PAVEL, KAMANOVÁ VENDULA, ZUZANA REČKOVÁ, MÁCHAL LADISLAV. 2018. Growth and Meat Quality of Prestice Black-Pied and (Landrace $\times$ Large White) $\times$ Duroc Pigs. Acta Universitatis Agriculturae et Silviculturae Mendelianae Brunensis, 66(3): 701-705.
\end{abstract}

The objective of the performed experiment was to evaluate growth performance and selected carcass traits and meat quality parameters in pigs of a native Czech breed Prestice Black-Pied pig (PB) and a commercial hybrid $(\mathrm{H})$ used for meat production. The observation included 40 pigs, 20 pigs of the native breed PB and 20 pigs of the hybrid combination. The PB piglets showed higher $(\mathrm{P} \leq 0.05)$ birth weight than the $\mathrm{H}$ piglets. The lifetime weight gain was higher $(\mathrm{P} \leq 0.01)$ in the $\mathrm{H}$ pigs than in the $\mathrm{PB}$ pigs. The results also showed higher $(\mathrm{P} \leq 0.01)$ backfat thickness in the $\mathrm{PB}$ breed than in the $\mathrm{H}$ pigs. Lean meat content was higher $(\mathrm{P} \leq 0.01)$ in the hybrid pigs than in the PB breed. Higher $(\mathrm{P} \leq 0.01)$ values of intramuscular fat content were found in the $\mathrm{PB}$ pigs than in the $\mathrm{H}$ pigs. Drip loss value was higher ( $\mathrm{P} \leq 0.01)$ in the $\mathrm{H}$ pigs by $1.3 \%$ than in the $\mathrm{PB}$ pigs. The $\mathrm{PB}$ pigs showed more favourable $(\mathrm{P} \leq 0.05)$ values of $\mathrm{pH}_{45,24}$ in comparison with the hybrid pigs.

Keywords: pig, Prestice Black-Pied breed, hybrid, carcass traits, meat quality

\section{INTRODUCTION}

Hybrids of modern pig breeds seem the most perspective option in terms of meat production. The analyses performed by Tang et al. (2008), Kasprzyk et al., 2015 and Nevrkla et al., 2017 lead to conclusion that pig breeds which are currently not used for commercial production may be a certain alternative for modern breeds as they represent qualities that might be lacking in the modern breeds, particularly higher resistance and higher meat quality (texture, fat content, more favourable $\mathrm{pH}$, etc.) at the same time. The differences in growth intensity, fat deposition, carcass traits and meat quality between the Basque Black-Pied pig and the Large White pig were described by Alfonso et al. (2005). The Basque Black-Pied pigs showed lower growth intensity, but higher levels of fat deposition (average backfat thickness was $2.6 \mathrm{~cm}$ in this breed). Also Csapó et al. (1999) found statistically significant differences in growth intensity and backfat thickness between the Mangalica breed and Large White $\times$ Mangalica and Mangalica $\times$ Duroc hybrids The Mangalica breed showed lower growth intensity and higher fat content than the observed hybrids. Wood et al. (2004) state that modern pig genotypes (Duroc, Landrace, Large White) grow faster, have thinner backfat and higher lean meat content when compared to regional breeds such as Tamworth and Berkshire. Effect of breed was also confirmed for intramuscular fat content, the modern breeds (Duroc, Large White, Landrace) show lower intramuscular fat content than the primitive 
breeds (Tamworth) and their conclusions suggest that the primitive breeds can be characterized by better meat stability $(\mathrm{pH})$. Similar conclusions were published by Zhang et al. (2009) who analysed the Duroc, Chester White, Berkshire, Yorkshire, Landrace and Hampshire breeds. The authors found higher fat content in carcass of Chester White, Berkshire and Duroc breeds together with lower drip loss value in comparison with Yorkshire, Landrace and Hampshire breeds. In the Czech Republic, there is also a breed that is characterized by lower growth intensity and higher fat content in carcass. It is Prestice Black-Pied pig (PB). In PB pigs, lower reproductive performance and higher backfat and intramuscular fat content have been described in comparison with more modern pig breeds. Neverthless, this breed is more resistant, it is very tolerant to worse housing conditions and can be used for outdoor breeding systems (Matoušek et al., 2016).

The objective of the performed study was to evaluate growth performance and selected carcass traits and parameters of meat quality in a native Czech breed Prestice Black-Pied pig and in a commercial hybrid used for meat production.

\section{MATERIALS AND METHODS}

The experimental population included 40 pigs. These pigs were divided into two groups according to their genotype. Twenty individuals were purebred Prestice Black-Pied pigs (PB) and twenty individuals were hybrids of Large White and Landrace in maternal position and Duroc in paternal position (H). Each group consisted of ten gilts and ten boars. Housing conditions met all regulations applicable in the Czech Republic.

The animals were fed ad libitum for the duration of the experiment with a complete feeding mixture which was identical for both the observed groups.

After termination of the observation, the pigs were slaughtered at a slaughterhouse. The criterion for slaughter was weight of the pigs, the required average slaughter weight was $110 \mathrm{~kg}$ for each group. The H pigs were slaughtered first, followed by the PB pigs. Carcasses were classified by the ZP method (Zwei-Punkt-Verfahren) of the SEUROP System
(European Union 2005/1/ES) at the slaughterhouse. Measurements of the meat quality parameters were performed on the left side of each carcass. At the time of 24 hours after the slaughter, samples of Musculus longissimus lumborum et thoracis (MLLT) and backfat from loin were collected from the region between the second and the third last rib and transported in a portable refrigerator to the laboratory.

Estimation of the drip loss was performed during the period of 24-48 h after slaughter, by weighing $150 \mathrm{~g}$ of meat hanging in a bag at $5^{\circ} \mathrm{C}$. Samples were then packed in PE bags and stored at $-20^{\circ} \mathrm{C}$ until analysis. The content of intramuscular fat was determined according to CSN ISO 1444 (1997) by extraction in a Soxtec 1043 apparatus (FOSS Tecator AB, Hoganas, Sweden). Muscle pH was measured using a portable $\mathrm{pH}$ meter ( $\mathrm{pH}$ 340i) equipped with a glass electrode at $45 \mathrm{~min}$ and $24 \mathrm{~h}$ post-mortem in fresh samples.

The data were analysed using software QC expert (TriloByte Statistical Software Ltd.) and the t-test was performed.

\section{RESULTS AND DISCUSSION}

Tab. I presents birth weight of piglets, slaughter weight and mean daily gain from birth to slaughter in the observed animals. The PB piglets showed higher $(\mathrm{P} \leq 0.05)$ birth weight than $\mathrm{H}$ piglets, by $0.12 \mathrm{~kg}$. No difference was found in the slaughter weight between the observed groups. The lifetime daily gain was higher in the PB pigs, by $70.92 \mathrm{~g}$. Matoušek et al. (2016) observed lifetime daily gain of $622 \mathrm{~g}$ in the PB pigs slaughtered with weight $106 \mathrm{~kg}$, but the parameter was evaluated from the age of 45 days. Maiorano et al. (2013) evaluated growth intensity from day 90 to day 330 in various pig genotypes. They recorded the lowest growth intensity value (478 g) in the Casertana breed, the value in the Duroc $\times$ (Landrace $\times$ Italian Large White) hybrid was $674 \mathrm{~g}$ and in the Italian Large White breed $739 \mathrm{~g}$. Similar results were presented by Robina et al. (2013) who point out lower growth intensity of the Iberian breed in comparison with the Duroc breed. The values of mean daily gain between the days $76-177$ were

I: Growth parameters in the evaluated pigs

\begin{tabular}{lccccccc}
\hline Parameter & Pigs & Mean & S.E. & $\mathbf{V}_{\mathbf{x}}$ & Min. & Max. & Significance \\
\hline Birth weight $(\mathbf{k g})$ & $\mathrm{PB}$ & 1.50 & 0.05 & 15.22 & 1.32 & 1.63 & $*$ \\
& $\mathrm{H}$ & 1.38 & 0.06 & 16.16 & 1.12 & 1.50 & 118.00 \\
\hline Slaughter weight $(\mathbf{k g})$ & $\mathrm{PB}$ & 112.44 & 2.27 & 5.75 & 105.00 & 120.00 \\
& $\mathrm{H}$ & 110.81 & 2.05 & 8.47 & 102.00 & 602.31 \\
Lifetime daily gain $(\mathbf{g})$ & $\mathrm{PB}$ & 558.21 & 21.51 & 11.35 & 505.14 & 721.00 \\
\hline
\end{tabular}

PB - Prestice Black-Pied pig, $\mathrm{H}$ - (Large White $\times$ Landrace) $\times$ Duroc, ns - non-significant $\mathrm{P} \geq 0.05 ;$ * - statistical significance $\mathrm{P} \leq 0.05 ; * *$ - statistical significance $\mathrm{P} \leq 0.01$ 
$390 \mathrm{~g}$ in the Iberian breed and $528 \mathrm{~g}$ in the Duroc. Between the days 194-227 it was $429 \mathrm{~g}$ against 539 and between the days 227-289 it was $549 \mathrm{~g}$ against $587 \mathrm{~g}$. Szulc et al. (2012) evaluated growth intensity of the Złotnicka Spotted breed and hybrids of Złotnicka Spotted and Duroc. They confirmed that the higher share of the Duroc in the hybrid the higher is its growth intensity.

Tab. II presents selected parameters of meat quality. The results show that the PB breed has higher $(\mathrm{P} \leq 0.01)$ backfat thickness $(6.29 \mathrm{~mm})$ than the $\mathrm{H}$ pigs. The lean meat content was higher $(\mathrm{P} \leq 0.01)$ in the hybrid pigs than in the $\mathrm{PB}$ breed by $4.58 \%$. The recorded values of intramuscular fat content were higher $(\mathrm{P} \leq 0.01)$ in the $\mathrm{PB}$ pigs than in the $\mathrm{H}$ pigs by $0.86 \%$. The drip loss value was higher $(\mathrm{P} \leq 0.01)$ in the $\mathrm{H}$ pigs than in the $\mathrm{PB}$ breed by $1.3 \%$. The observation performed by Nevrkla et al. (2017) on Prestice Black-Pied pig and a four-breed hybrid document that the PB pigs have thicker layer of backfat by nearly $8 \mathrm{~mm}$ when compared to the observed hybrid and also their lean meat content was lower by $6 \%$ and their intramuscular fat content (IMF) was higher by $8 \%$. The value of drip loss was higher in the hybrid by $2.20 \%$. Meat stability determined by the $\mathrm{pH}$ value was more favourable in the PB pigs. This study brings similar findings, however with evident differences in results, mainly with respect to the boars used, which documents the effect of hybrid combination. Also Dostálová et al. (2012) described higher IMF content in PB pigs (17.3 g) than in a hybrid $(15.2 \mathrm{~g})$, the authors emphasize that this difference is even more pronounced when pigs are bred in the organic regime. Differences in qualitative parameters of meat among pig genotypes were described also by Fortina et al. (2005), who compared the breeds Casertana and Mora and found higher values of backfat thickness at last rib in the Mora breed by $9 \mathrm{~mm}$ against the Casertana breed. They also highlighted differences in $\mathrm{pH}$ values. In the Casertana breed the $\mathrm{pH}_{45}$ was 6.38 and $\mathrm{pH}_{24}$ was 5.96 while in the Mora breed the values were 6.57 and 6.15. Franco et al. (2014) performed an observation in the Celta breed and hybrids of Celta $\times$ Duroc and Celta $\times$ Landrace. The authors proved that the native Celta breed shows higher IMF content than the hybrids together with lower $\mathrm{pH}$ values of the meat. Differences among genotypes were documented also in Asian pig breeds. Jiang et al. (2011) described following values in the Dahe breed: backfat thickness $4.12 \mathrm{~cm}, \mathrm{pH}_{24}$ 6.45 and drip loss $2.19 \%$ against the Dawu breed with values: backfat thickness $2.23 \mathrm{~cm}, \mathrm{pH}_{24} 6.25$ and drip loss $1.88 \%$. The observed differences were statistically significant $(\mathrm{P} \leq 0.01)$. Radovic et al. (2017) found differences in the size of back muscle among various pig breeds (Moravka, Mangalica) and hybrids (Mangalica $\times$ Moravka, Duroc $\times$ Moravka) used in Serbia. In hybrids with the Duroc, the area of back muscle was the highest. Wojtysiak and Połtowicz (2014) performed an evaluation of native Polish Pulawska pigs slaughtered at the weight of $100 \mathrm{~kg}$ with backfat thickness $23.64 \mathrm{~mm}$ against $13.22 \mathrm{~mm}$ found in the Polish Large White pigs. The lean meat content was higher in the Polish Large White breed than in the Pulawska breed (592 vs. $497 \mathrm{~g} / \mathrm{kg}$ ). Results of the above mentioned studies correspond to the results of the present study and indicate that native breeds show higher intramuscular fat content and lower lean meat content, however they are characterized by higher meat stability.

II: Parameters of meat quality in the evaluated pigs

\begin{tabular}{|c|c|c|c|c|c|c|c|}
\hline Parameter & Pigs & Mean & S.E. & $\mathbf{V}_{\mathbf{x}}$ & Min. & Max. & Significance \\
\hline \multirow{2}{*}{$\begin{array}{l}\text { Backfat thickness } \\
\text { (mm) }\end{array}$} & PB & 23.54 & 5.82 & 13.14 & 18.22 & 30.12 & \multirow{2}{*}{$* *$} \\
\hline & $\mathrm{H}$ & 17.25 & 4.96 & 9.26 & 14.68 & 24.87 & \\
\hline \multirow{2}{*}{ Lean meat content (\%) } & $\mathrm{PB}$ & 51.76 & 0.67 & 3.66 & 48.50 & 53.90 & \multirow{2}{*}{$* *$} \\
\hline & $\mathrm{H}$ & 56.35 & 0.75 & 5.97 & 48.80 & 61.60 & \\
\hline \multirow{2}{*}{ Intramuscular fat (\%) } & $\mathrm{PB}$ & 2.89 & 0.15 & 14.61 & 2.12 & 3.37 & \multirow{2}{*}{$* *$} \\
\hline & $\mathrm{H}$ & 2.03 & 0.09 & 15.50 & 1.73 & 3.00 & \\
\hline \multirow{2}{*}{ Drip loss (\%) } & $\mathrm{PB}$ & 2.65 & 0.18 & 18.84 & 1.79 & 3.45 & \multirow{2}{*}{$* *$} \\
\hline & $\mathrm{H}$ & 3.95 & 0.19 & 17.53 & 2.03 & 4.78 & \\
\hline \multirow{2}{*}{$\mathrm{pH}_{45}$} & PB & 6.12 & 0.14 & 4.94 & 5.26 & 6.19 & \multirow{2}{*}{ * } \\
\hline & $\mathrm{H}$ & 6.02 & 0.09 & 4.45 & 5.18 & 6.15 & \\
\hline \multirow{2}{*}{$\mathrm{pH}_{24}$} & $\mathrm{~PB}$ & 5.61 & 0.04 & 2.41 & 4.97 & 5.85 & \multirow{2}{*}{$*$} \\
\hline & $\mathrm{H}$ & 5.49 & 0.11 & 8.72 & 4.70 & 6.05 & \\
\hline
\end{tabular}

PB - Prestice Black-Pied pig, H - (Large White $\times$ Landrace) $\times$ Duroc, ns - non-significant $\mathrm{P} \geq 0.05$; * statistical significance $\mathrm{P} \leq 0.05 ;{ }^{* *}$ - statistical significance $\mathrm{P} \leq 0.01$ 


\section{CONCLUSION}

The experiment confirmed significant differences in growth intensity and meat quality between the native breed Prestice Black-Pied pig of Czech origin and the three-breed hybrid of pigs for commercial meat production. The pigs of the PB breed expressed lower growth intensity from birth to slaughter than the hybrid pigs. The backfat thickness and intramuscular fat content were higher and the lean meat content was lower in the PB pigs, which significantly decreases the chances of the breed to be used in common commercial production. However, the drip loss value, and the $\mathrm{pH}_{45}$ and $\mathrm{pH}_{24}$ values indicate that meat of the PB pigs can be characterized by higher stability. It can be concluded that meat of the PB pigs is suitable for consumers, who search for higher fat content related to better texture and juiciness of meat.

Acknowledgement

This study was supported by the project of MENDELU internal grant agency, Faculty of AgriSciences No. TP 7/2017.

\section{REFERENCES}

ALFONSO, L., MOUROT, J., INSAUSTI, K., MENDIZABAL, J. A. AND ARANA, A. 2005. Comparative description of growth, fat deposition, carcass and meat quality characteristics of Basque and Large White pigs. Anim. Res., 54(1): 33-42.

CSAPÓ, J., HÚSVÉTH, F., CSAPÓ-KISS, Z., HORN, P., HÁZAS, Z. AND VARGA-VISI, É. 1999. Fatty acid composition and cholesterol content of the fat of pigs of various genotypes. In: $50^{\text {th }}$ Annual Meeting of the European Association for Animal Production, Zürich.

ÚNMZ. 1997. Meat and Meat Products. Determination of Free Fat Content. CSN ISO 1444. Prague: Czech Standards Institute.

DOSTÁLOVÁ, A., KOUCKÝ, M., VALIŠ, L. and ŠIMEČKOVÁ, M. 2012. Evaluation of fattening performance, carcass traits and meat characteristics of prestice black-pied pigs in the organic free-range and conventional systém. Res. Pig. Breed., 6(2): 15-19.

EUROPEAN UNION. 2005. Commission decision of 27 December 2004 authorising methods for grading pig carcases in the Czech Republic. EU decision 2005/1/ES. Official Journal of the European Union.

FORTINA, R., BARBERA, S., LUSSIANA, C., MIMOSI, A., TOSSONE, S., ROSSI, A. AND ZANARDI, E. 2005. Performances and meat quality of two Italian pig breeds fed diets for commercial hybrids. Met Sci., 71: 713-718.

FRANCO, D., vazques, j. a. and lorenzo, j. m. 2014. Growth performance, carcass and meat quality of the Celta pig crossbred with Duroc and Landrance genotypes. Met Sci., 96: 195-202.

JIANG, I. Z., ZHU, L., LI, X. Z. AND SI, T. 2011. Evaluation of the Chinese indigenous pig breed Dahe and crossbred Dawu for growth and carcass characteristics, organ weight, meat quality and intramuscular fatty acid and amino acid composition. Animal., 5: 1485-1492.

KASPRZYK, A., TYRA, M. AND BABICZ, M. 2015. Fatty acid profile of pork from a local and a commercial breed. Arch. Anim. Breed., 58:379-385.

MAIORANO, G., GAMBACORTA, M., TAVANIELLO, S., D’ANDREA, M., STEFANON, B. AND PILLA, F. 2013. Growth, carcass and meat quality of Casertana, Italian Large White and Duroc $\times$ (Landrace $\times$ Italian Large White) pigs reared outdoors. Ital. J. Anim. Sci., 12: 426-431.

MATOUŠEK, V., KERNEROVÁ, N., HYŠPLEROVÁ, K., JIROTKOVÁ, D. AND BRZÁKOVÁ M. 2016. Carcass Traits and Meat Quality of Prestice Black-Pied Pig Breed. Asian Australas. J. Anim. Sci., 29: 1181-1187.

NEVRKLA, P., KAPELAÑSKI, W., VÁCLAVKOVÁ, E., HADAŠ, Z., CEBULSKA, A. AND HORKÝ, P. 2017. Meat Quality and Fatty Acid Profile of Pork and Backfat from an Indigenous Breed and A Commercial Hybrid of Pigs. Ann. of Anim. Sci., 17: 1215-1227.

RADOVIC, C., PETROVIC, M., PARUNOVIC, N., RADOJKOVIC, D., SAVIC R., STANIŠIC, N. AND GOGIC, M. 2017. Carcass and pork quality traits of indigenous pure breeds (Mangalitsa, Moravka) and their crossbreads. Indian J. Anim. Res., 51: 371-376.

ROBINA, A., VIGUERA, J., PEREZ-PALACIOS, T., MAYORAL, A. I., VIVO, J. M., GUILLEN, M.T. AND RUIZ J. 2013. Carcass and meat quality traits of Iberian pigs as affected by sex and crossbreeding with different Duroc genetic lines. Span. J. Agric. Res., 11: 1057-1067.

SZULC, K., SKRZYPCZAK, E., BUCZYŃSKI, J.T., STANISŁAWSKI, D., JANKOWSKA-MAৃKOSA, A. AND KNECHT, D. 2012. Evaluation of fattening and slaughter performance and determination of meat quality in Złotnicka Spotted pigs and their crosses with the Duroc breed. Czech J. Anim. Sci., 57: 95-107.

TANG, Z., PENG, Z., LIU, B., FAN, B., ZHAO, S., LI, X. AND XU, S. 2008. Effect of breed, sex and birth parity on growth, carcass and meat quality in pigs. Front. Agric. China., 2: 331-337. 
WOJTYSIAK, D. AND PO€TOWICZ, K. 2014. Carcass quality, physico-chemical parameters, muscle fibre traits and myosin heavy chain composition of m. longissimus lumborum from Puławska and Polish Large White pigs. Met Sci., 97: 395-403.

WOOD, J. D., RICHARDSON, R. I., NUTE, G. R., FISHER, A. V., CAMPO, M. M., KASAPIDOU, E., SHEARD, P. R. AND ENSER, M. 2004. Effects of fatty acids on meat quality: a review. Meat Sci., 66: 21-32.

ZHANG, S., KNIGHT, T. J., STALDER, K. T., GOODWIN, R. N., LONERGAN, S. M. AND BEITZ, D. C. 2009. Effects of breed, sex and halothane genotype on fatty acid composition of triacylglycerols and phospholipids in pork longissimus muscle. J. Anim. Breed. Genet., 126: 259-268. 